\title{
I am the emu
}

Melitta Hogarth

University of Southern Queensland

Melitta.Hogarth@usq.edu.au

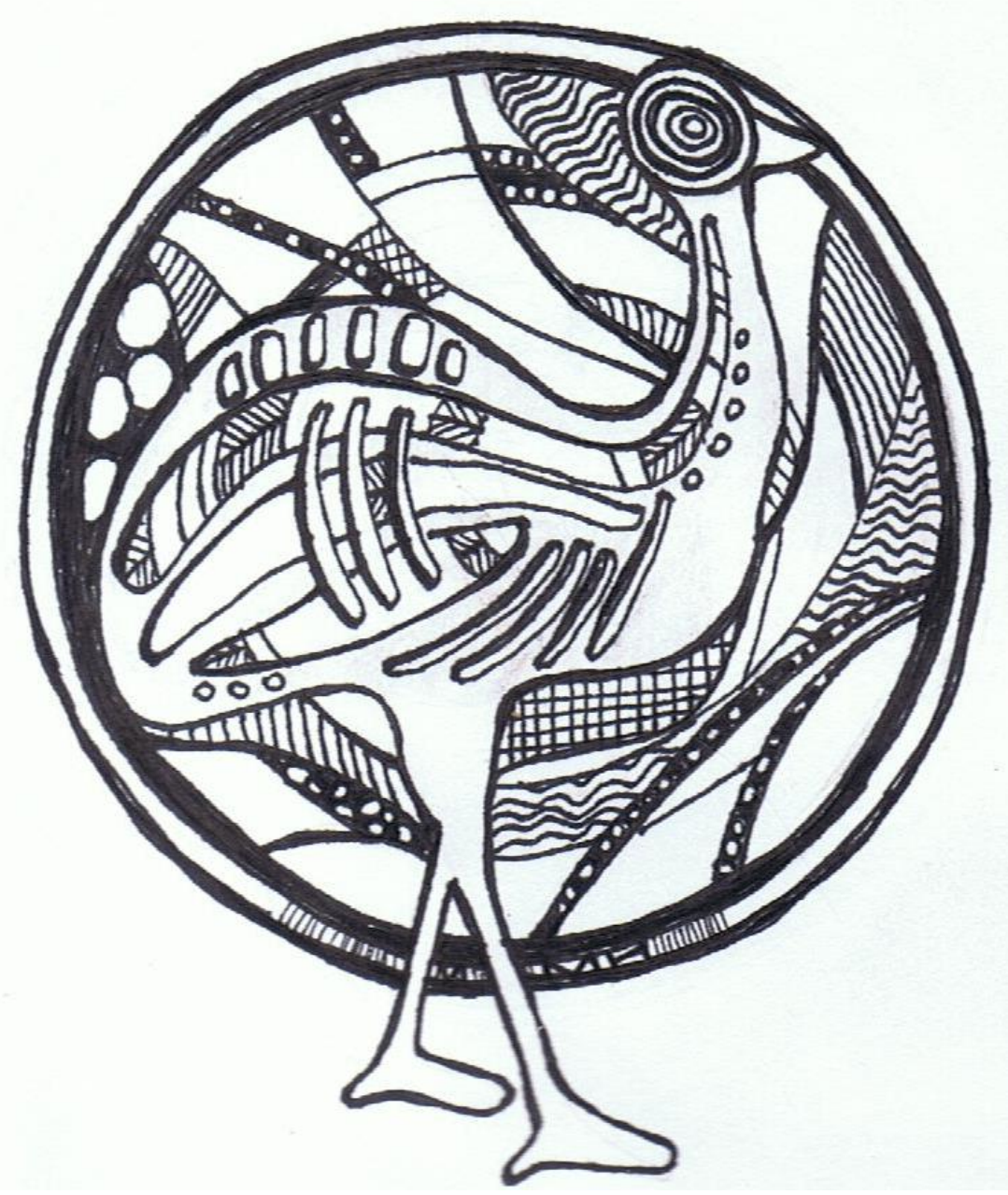

Melitta Hogarth, I am the emu (Ink Drawing), 2017

Ink Drawing, $10 \times 10 \mathrm{cms}$. PhD Thesis, Addressing the rights of Indigenous peoples in education: A critical analysis of Indigenous education policy, Queensland University of Technology, 2018 (pp. xxix; 385). [Unpublished].

I

I am me. I am the emu. I am one with the land, the waters and the air. I am connected to this land through my bloodlines. I too have a right in this space. My story is just one of the emerging narratives in Indigenous history. I claim 
my space. I claim my place. I claim my Aboriginal identity. I speak from within; seeking a place to assert my position. I am a teacher. I am a learner. I am but one of many crying for our voices to be heard.

\section{II}

But our voices are muted by the overseer. The 'learned' coloniser who assumes they are the 'knower'. Through the centuries, they have sought to keep us down; to diminish our knowledges, our understandings, our worldviews. For they are the 'civilised' and we are not.

\section{III}

But we have survived and we have resisted; our connections to Country remain. The inner strength of the people cannot be denied. Our tenacity to adapt to any environment taunts them. We still are here and proud.

\section{IV}

They try to take away our identities. They establish their definitions of our Indigeneity. Our skin colour, our removal from Country and family; a result of their actions, are their arguments for their denial. The calls to prove our identity through their measures remain. 
And today, they claim to celebrate our Indigeneity. Our ways are 'stolen', adapted and appropriated; a means in which they include to establish their connection and belittle ours. They make their own claims. I was born here too, they call.

\section{VI}

They stand on their pedestals with their rhetoric.

Continuously, questioning our position, asking why we do not engage in their schools. They ignore the past; the horrors and atrocities, for their preferred futures. Just move on they say.

\section{VII}

The inequities they see. Embrace the opportunities provided to you, they assert; and then blame you when you do not succeed. The gap must be closed, they say. But by whose values? By whose standards? The cycle of control begins again. The cyclic motion where our spirit and heart aches but is warmed by the fires of resistance once more.

\section{VIII}

I am me. I am the emu. I am one with the land, the waters and the air. I am connected to this land through my bloodlines. I too have a right in this space. My story is just one of the emerging narratives in Indigenous history. I claim my space. I claim my place. I claim my Aboriginal identity. 